\title{
Evaluation of chronic statin treatment on sepsis outcome in I.C.U
}

\author{
HAA Youssef*, HM Koptan, A Moustafa \\ From ESICM LIVES 2015 \\ Berlin, Germany. 3-7 October 2015
}

Severe sepsis and septic shock are common and frequently fatal problem in I.C.U. Recent therapeutic advances to routine clinical practice has proven controversial, because of their pleiotropic effects related to many pathophysiological determinants of sepsis. Statin therapy could be the next step in the search for adjuvant therapy. This study was done to evaluate chronic statin therapy on outcome of patients with sepsis and septic shock in I.C.U

\section{Methods}

We compared patients with severe sepsis and septic shock. Two groups were identified, group A, patients didn 't receive statin before or during their I.C.U management. Group B, patients with ongoing statin therapy before admission and continued during I.C.U therapy. The primary end point was the number of organ failure free days, hemodynamic failure free days and organ dysfunction free days up to day 14. Secondary endpoints included hospital mortality and safety.

\section{Results}

Patients in whom chronic statin therapy had been continued in the I.C.U $(n=45)$ had significantly more organ failure free days 12(5-15), organ dysfunction free days 10(2-13), hemodynamic failure free days $13(9-14)$ as compared to others non statin $\operatorname{group}(\mathrm{n}=33)$ with organ failure fee days $5(0-11)$, organ dysfunction free days $2(0-$ $10)$, and hemodynamic failure free days $9(6-12)$. The need for increased mortality and hospital length of stay were comparable in the two groups.

\section{Conclusions}

Chronic statin therapy in I.C.U septic patients was associated with reduction in the severity of organ failure and

Faculty of Medicine, Menoufyia University, Anesthesia, Menoufia, Egypt hemodynamic failure with no improvement in hospital mortality and length of stay.

Published: 1 October 2015

\section{References}

1. Casanouva MP, Pena JM, Rodroguez V, Ortega M: Severe sepsis and septic shock. Revista Espan Anestes 2007, 54(8):484-98.

2. Baignet C, Keech A, Kearney PM, Blackwell L, Buck G, Pollicino C, Kirby A, Sourjina T, Peto R, collins R, simes R, Cholesterol treatment Trialists'(CTT) collaborators: Efficacy and safety of cholesterol-lowering treatment: Prospective meta-analysis of data from 90.056 participants in 14 randomized trials of statins. Lancet 2005, 366:1267-1278.

3. Mekontso-Dessap A, Brun-Buisson C: Statins: the next step in adjuvant therapy for sepsis? Intensive Care Med 2006, 32:11-14.

4. Jacobson JR: Statins in endothelial signaling and activation. Antioxid Redox signal 2009, 11:811-821.

5. Janda S, Young A, Fitzgerald JM, Etminan M, Swiston J: The effect of statins on mortality from severe infections and sepsis: a systematic reviewand meta-analysis. J Crit Care 2010, 25:656, e657-622.

doi:10.1186/2197-425X-3-S1-A872

Cite this article as: Youssef et al:: Evaluation of chronic statin treatment on sepsis outcome in I.C.U. Intensive Care Medicine Experimental 2015 3(Suppl 1):A872.

\section{SpringerOpen $^{\circ}$}

(C) 2015 Youssef et al.; This is an Open Access article distributed under the terms of the Creative Commons Attribution License (http:// creativecommons.org/licenses/by/4.0), which permits unrestricted use, distribution, and reproduction in any medium, provided the original work is properly cited.
Submit your manuscript to a SpringerOpen ${ }^{\bullet}$ journal and benefit from:

- Convenient online submission

- Rigorous peer review

- Immediate publication on acceptance

- Open access: articles freely available online

- High visibility within the field

Retaining the copyright to your article

Submit your next manuscript at $>$ springeropen.com 